\title{
THE ETHNOCULTURE OF THE NORTH CAUCASUS AS A FACTOR OF COUNTERACTION TO EXTREMISM AMONG YOUTH
}

\author{
(C) Madina Z. Magomedova
}

\author{
Regional centre of ethnopolitical sciences of Dagestan Scientific Center \\ of Russian Academy of Sciences, Dagestan State University of National Economy, \\ Russian Federation \\ spirow@mail.ru
}

The ethnoculture of the peoples of the North Caucasus is a part of the common cultural heritage of the peoples of Russia. It has a great social, cultural and political significance. In the context of globalization, it is important to preserve the national languages, traditions, folklore and originality of all North Caucasian peoples. It is also important to create the conditions for their free national self-affirmation and popularization of the ethnocultural heritage. The research of the problems of the traditional culture of the North Caucasian peoples is especially actualized by the leveling the significance of ethnocultural values in the Russian society. Preserving ethnoculture is also one of the important factors in countering extremist ideology in the North Caucasus, whose supporters, using the influence of religion in the region, are trying to distort the meaning of the ideas laid down in Islam, pulling them out of the context and treating them tendentiously. Conducting preventive measures among young people is much more productive than the elimination of the consequences of their extremist and terrorist activities. Radical religious organizations use misinformation, intimidation, manipulation of public consciousness, the substitution of concepts and facts extensively, use the Internet for recruiting of new members, including suicide bombers. In contrast to the activities of destructive forces in society, it is necessary to recall and revive the traditional values of the peoples of the North Caucasus, on which our ancestors relied: honoring their elders, mentoring young people, protecting women and children, respecting the traditions of their ancestors, etc. If this foundation, on which the whole social structure was built in the Caucasus, collapses then the younger generation will have nothing to build its future on.

Key words: ethnoculture, traditional culture, polyethnicity, polyconfessionality, the North Caucasus, ethnoconfessional tolerance, Islam, extremism, the youth.

\section{[M.3. Магомедова Этнокультура Северного Кавказа как фактор противодействия экстремизму среди молодежи]}

Этнокультура народов Северного Кавказа является частью общего культурного наследия народов России. Велико ее социальное, культурное и политическое значение. В условиях глобализации важно сохранить национальные языки, традиции, фольклор, самобытность всех северокавказских народов, создать условия для их свободного национального самоутверждения и популяризации этнокультурного наследия. Исследование проблем традиционной культуры северокавказских народов особо актуализируется нивелированием значимости этнокультурных ценностей в российском обществе. Сохранение этнокультуры также является одним из важных факторов противодействия экстремистской идеологии на Северном Кавказе, сторонники которой, пользуясь влиянием религии в регионе, пытаются исказить смысл заложенных в исламе положений, вырывая их из контекста и тенденциозно трактуя. Проведение профилактических мероприятий среди молодежи намного продуктивнее, нежели ликвидация последствий их экстремистской и террористической деятельности. Радикальные религиозные организации широко используют дезинформацию, запугивание, манипуляцию общественным сознанием, подмену понятий и фактов, используют Интернет для вербовки новых членов, включая террористов-смертников. В противовес деятельности деструктивных сил в обществе необходимо вспомнить и возродить традиционные ценности народов Северного Кавказа, на которые опирались наши предки: почитание старших, наставничество молодежи, защита женщин и детей, уважение традиций предков и др. Если этот фундамент, на котором строился весь общественный уклад на Кавказе, разрушится, то молодому поколению не на чем будет строить свое будущее.

Ключевые слова: этнокультура, традиционная культура, полиэтничность, поликонфессиональность, Северный Кавказ, этноконфессиональная толерантность, ислам, экстремизм, молодежь.

Madina Z. Magomedova - candidate of philosophical sciences, the leading scientific worker of the Regional Centre of Ethnopolitical sciences. Dagestan Scientific Center of Russian Academy of Sciences; associate pro- 
fessor of Department of Humanitarian Disciplines. Dagestan State University of National Economy, Makhachkala, Russian Federation.

Магомедова Мадина Зайнудиновна - кандидат фрилософрских наук, ведущий научный сотрудник Регионального центра этнополитических исследований Дагестанского научного центра PAН; доцент кафедры гуманитарных дисциплин Дагестанского университета народного хозяйства, г. Махачкала, Российская Федерация.

The ethnocultural heritage is a part of the general heritage of humankind. It is a powerful tool of rapprochement of the peoples, of the approvals of their cultural originality. It has a great social, economic, cultural and political significance. Nowadays, in the context of globalization, it is important to preserve deep, fundamental basis of multinational culture of our state, traditional culture, national languages, folklore and national originality of each folk of Russia. It is also important to create the conditions for their free national self-affirmation and popularization of the ethnocultural heritage for the purpose of preservation of one cultural space of Russia. It is important to reveal the basic trends of cultural development of the North Caucasian people.

The traditional culture of the peoples of Russia is the most important part of the national culture and national consciousness, strengthening a spiritual connection of generations. The question of the revival of national cultural traditions is fundamental for the development of statehood. In the interests of future generations, it is necessary to tend to keep the identity, originality and uniqueness of each ethnic group in the multinational state and also to create the atmosphere of mutual respect and cooperation in it.

Globalization, washing away the ethnic identity, is not capable to destroy it completely, to create a new person out of ethnos and culture. In the crisis moments of life, the man addresses the ethnic connections and the relations providing the feeling of stability that it is quite often possible to observe in the modern world. Nowadays the globalization trends are shown in all more or less significant spheres of public life. In this respect the ethnocultural processes in Russia are not the exception and, especially those which proceed in the South of the country. The North Caucasus is at the junction of world civilizations, differs in an ethnoconfessional variety, it is the motliest region of the Russian Federation on the ethnic and religious palette. For the Caucasus, as the center of the unique peoples and cultures, the social and spiritual integrity of the Russian multinational people is of particular importance. The North Caucasus is the whole world of the peoples, cultures and languages which has been developing and interacting in this territory for thousands of years. Here the peculiar original North Caucasian culture which had absorbed hundreds of various ethnic cultural traditions was created.

The North Caucasus is a very manifold region on the structure of the indigenous peoples inhabiting it, representing the uniform system of ethnic groups, with the high density of compact resettlement of ethnic groups. The North Caucasian peoples have not only got closely interconnected historical ways of development, community of geographic location and the specific place in the system of interregional interactions. They have peculiar ethnicity, complex mix of mentality and culture which distinguishes these peoples from other communities. The relevance of the research of the problem of traditional culture of the North Caucasian peoples is caused by the leveling of the importance of ethnocultural values in the Russian society against the background of the strengthening of the interethnic and interfaith tension. In the modern world, hostility to the foreign groups, xenophobia, gains the mass character and becomes one of the most serious problems. Nowadays the most extended forms of xenophobia are ethnophobia, religious phobia and phobia of migrants. As A.G. Asmolov notes: "If there was no tolerance as a universal form of existence of various forms of evolutionary development, then waves of aggression, conflicts, intolerance, fanaticism, genocide, 
xenophobia, ethnophobia, phobia of people would erase any manifestations of a variety on the Earth long ago. And the general homogeneity, uniformity, totalitarianism, greyness, immovability would set in the world" [1, p. 5].

Therefore, it is natural that the ethnoconfessional tolerance acts as the main dominant of many acts of the Russian Federation regulating the ensuring of national security, sustainable social and economic development of the country and regions, the formation of installations of tolerant consciousness and prevention of extremism in the Russian society. So, in the fifth article of the Federal law of July 25, 2002 "About counteraction to extremist activity" it is said: "Federal organs of the government, public authorities of territorial subjects of the Russian Federation, local government bodies within their competence on a priority basis carry out the preventive, including educational, propaganda measures directed to the prevention of extremist activity" [5, p. 21].

In many cases the religious component often presents among the reasons of ethnopolitical tension and in itself does not act as an independent source of the conflicts. The conflict of the inter-confessional and intra-confessional relations is connected with the disorder of life and vulnerability of people in the social sphere. The main conditions of stability in society are the personal factor, subjective internal readiness to be tolerant to others and more demanding to themselves and also the initiative of people by the definition of their ethnocentrist trends and religious prejudices, determination to reduce personal intolerance and intolerance of other people in interaction. The position of peacefulness, trust and high culture is the basis of positive development of society, peaceful co-existence, but not of the conflict.

The main reasons of ethnoconfessional tension in the North Caucasus are caused by the features of a geopolitical position of the region and of a social and economic level of living of people. They are connected with the general crisis which captured the country, with the mistakes and shortcomings of carrying out national policy and employment policy, with the intervention of criminal groups in the solution of socio-political questions, with the low living standards, with migration etc. The ethnic variety and the multi-ethnicity characteristic for the North Caucasus, in itself, are not the reasons of conflictogenity.

According to T.A. Ovsyannikova, the major factor of the revival of traditional culture in the North Caucasus, first, should be considered the ethnic consciousness of peoples of the region. The natural loss of separate elements of traditional culture led to the fact that only its basic elements, but not all cultural contour in general revive. Therefore, in general, there is its specificity, which characterizes the culture only of the certain ethnos. Secondly, the revival of traditional culture of the North Caucasus does not mean the refusal of all modern culture and it is almost impossible. Therefore, cultural development in the North Caucasus is, as a rule, one of the elements of its revival and reanimation. It should be noted that the development is not limited only by the revival; it is a many-sided and versatile process. All this allows giving the generalized characteristic of cultural process in the North Caucasus. There is a formation of a regional originality. At the same time analyzing the trends of the revival of the North Caucasian culture it is necessary to consider the huge influence of Islam on it. But is Islam capable to become a dominant or even a source, along with traditions, of the cultural revival of the North Caucasus? Time will give the final answer to this and other questions of Islam role in the cultural revival of the region, which we are interested in. So far it is possible to speak about some probable scenarios of process of the cultural revival, depending on this essential variable (Islam) [4].

Supporters of extremist religious trends exaggerate of the intolerance elements, placed into Islam; treat the provisions of religion tendentiously, taking them out of the context, make emphasis on some doctrines to the detriment of others. For example, the statute of "jihad" which is contained in Koran is treated by Islamic extremists only as the usage of force 
against the "enemies". At the same time the word "jihad" in translation from Arabic is meant by "effort", the return of all forces for the sake of distribution and celebration of Islam.

Originally "jihad" was really meant mainly as military operations of the Muslim state. But, since IX-X centuries the concept "jihad" had been filled with new contents. There was an idea of the highest form of jihad, spiritual jihad, and the internal self-improvement on the ways to Allah and an idea of four types of jihad: jihad of a sword, jihad of a heart, jihad of a language and jihad of a hand.

Besides, the religious war is treated in Koran as defensive. Islam strictly forbids suicide, participation of women in the war and supports humane treatment of prisoners. It is forbidden to attack weak men, women and children, to exterminate the cattle, to destroy fields, to kill herd, to destroy constructions. It is not authorized to wage a war in sacred months.

The comparison of these statutes with practice of the Islamic radicals using terrorism actively, takings of hostages, murders of children and old men, terrorist attacks conducted by suicide bombers, including women, shows that they in their interests distort religious norms blatantly [2, p. 71].

Due to the extreme nature of the international terrorism and an unstable social and economic situation in the region, first of all, the young generation is under the influence of radical and extremist groups and their mass promotion. Young people live with a perspective on the future. The values, views and skills acquired by the present generation of youth and the choice which they will make today will affect the course of events and will be essential in formation of our future. During the growing-up, the man passes certain stages. Those young people who have no opportunity to get an education and to promote themselves in social hierarchy of society are more subject to the retraction into the extremist organizations, undermining social bases.

Explaining such rapid degradation of the spiritual sphere of the person in recent years, researchers emphasize that it occurs during transition periods when one system of values was exhausted or was violently destroyed, and another was not created yet. And the quicker and more rigidly these changes were entered, the losses in the field of public morality were felt more [3, p. 3]. Such transition period also occurred in the nineties when the state educational system of younger generation was destroyed.

Prevention and fight against manifestations of the international terrorism among young people is a business of extreme importance which has to be implemented in the sphere of cooperation between the public authorities which are engaged in development of youth policy, and the youth organizations. Taking into account that the legal bases of the fight against extremism and terrorism in Russia are the Constitution of the Russian Federation, the Criminal Code of the Russian Federation, the Federal law of March 6, 2006 N 35-FL "About counteraction to terrorism", the Federal law of July 25, 2002 N114-FL "About Counteraction to Extremist Activity", and other federal laws, decrees and orders of the Russian President, the resolutions and the orders of the Government of the Russian Federation. It is especially important to carry out preventive maintenance in the environment of youth because young generation, owing to a number of various factors, is the most vulnerable in respect of susceptibility to negative impact of various antisocial and criminal groups. The reasons allowing to extend the radical ideas in their environment are social and material vulnerability of youth, frequent maximalism in estimates and judgments, psychological immaturity and considerable dependence on others opinion. Leaders of extremist groups entice youth into their associations, promising the easy solution of all the problems, including material ones. Weak young minds often do not even think that, participating in the activity of similar formations, they not only do not solve the existing problems, but also create new problems for themselves, destroying their future. Certainly, it is much more useful to prevent extremism and terrorism among youth, than to liquidate consequences of the similar phenomena. 
The Internet becomes the most effective remedy of mass information impact of terrorists on youth. It is the easy access to the audience, supplying of anonymous communication; the weak control on the national level; global distribution, high speed of information transfer; multimedia opportunities, low cost and usability. Extremists widely use misinformation, intimidation, substitution of concepts and facts; they also use the Internet for recruitment of new members, including suicide bombers. They manipulate public consciousness. In contrast to the activities of destructive forces in society, it is necessary to recall and revive the traditional values of the peoples of the North Caucasus, on which our ancestors relied: honoring their elders, mentoring young people, protecting women and children, respecting the traditions of their ancestors, etc. If this foundation, on which the whole social structure was built in the Caucasus, collapses then the younger generation will have nothing to build its future on.

\section{Лumepamypa}

1. Асмолов А.Г. Слово о толерантности // Век толерантности. 2001. № 1.

2. Дмитриев А.В., Залысин И.Ю. Религиозный терроризм: сущность, истоки, разновидности // Религия в самосознании народа (Религиозный фактор в идентификационных процессах). Отв. ред. М.П. Мчедлов М.: Институт социологии РАН, 2008.

3. Никандров Н.Д. Духовные ценности и воспитание в современной России // Педагогика. 2008. № 9.

4. Овсянникова T.A. Традиционная культура народов Северного Кавказа (возрождение или развитие) // Вестник Майкопского государственного технологического университета. 2014. URL: https://cyberleninka.ru/article/n/traditsionnaya-kultura-narodovsevernogo-kavkaza-vozrozhdenie-ili-razvitie (дата обращения 28.08.18).

5. Федеральный закон «О противодействии экстремистской деятельности». М., 2005.

\section{References}

1. Asmolov A.G. Slovo o tolerantnosti. Vektolerantnosti [The word about tolerance. Century of tolerance]. 2001. No.1 (in Russian).

2. Dmitriev A.V., Zalysin I.Yu. Religioznyj terrorizm: sushchnost', istoki, raznovidnosti. Religiya $v$ samosoznanii naroda (Religioznyj faktor $v$ identifikacionnyh processah) [Religious terrorism: essence, sources, types. Religion in consciousness of the people (The religious factor in identification processes)]. The responsible editor is M.P. Mchedlov. Moscow. Institute of sociology of RAS, 2008 (in Russian).

3. Nikandrov N.D. Duhovnye cennosti I vospitanie v sovremennoj Rossii. Pedagogika [Cultural wealth and education in modern Russia. Pedagogics]. 2008. No 9. (in Russian).

4. Ovsyannikova T.A. Tradicionnaya kul'tura narodov Severnogo Kavkaza (vozrozhdenie ili razvitie) Vestnik Majkopskogo gosudarstvennogo tekhnologicheskogo universiteta. [Traditional culture of the peoples of the North Caucasus (revival or development). Bulletin of the Maykop state technological university]. 2014. Available at: https://cyberleninka.ru/article/n/traditsionnaya-kultura-narodov-severnogo-kavkazavozrozhdenie-ili-razvitie (accessed 28 August 2018) (in Russian).

5. Federal'nyj zakon «O protivodejstvii ehkstremistskoj deyatel'nosti» M. [Federal law "About Counteraction of Extremist Activity"]. Moscow, 2005 (in Russian). 